\title{
Az edoxabán véralvadásgátló hatásossága és biztonságossága nonvalvuláris pitvarfibrillációban
}

\author{
Szegedi Andrea dr. - Csanádi Zoltán dr. \\ Debreceni Egyetem, Általános Orvostudományi Kar, Klinikai Központ, \\ Kardiológiai és Szívsebészeti Klinika, Debrecen
}

\begin{abstract}
A pitvarfibrilláció a többszörösére emeli a stroke és a szisztémás embolizáció előfordulását, amelyek megfelelően beállított véralvadásgátló kezeléssel megelőzhetôk. A K-vitamin-antagonisták hatékonyan csökkentik a thromboembolia kockázatát, hatásukat azonban számos tényező befolyásolja. Az elmúlt években megjelenő új típusú, direkt orális antikoagulánsok megjelenésével új lehetőségek nyíltak a hatékony véralvadásgátló kezelés megválasztásában. Ebben a gyógyszercsoportban a legutóbb elérhetővé váló edoxabán az ENGAGE AF-TIMI 48 és az ENSURE-AF multicentrikus, randomizált vizsgálatok eredményei alapján a hagyományos tartós orális antikoaguláns terápiához hasonlóan hatásos, ugyanakkor jobban tolerálható véralvadásgátló kezelést jelent nem valvularis hátterü pitvarfibrillációban szenvedő betegek esetében.
\end{abstract}

Orv Hetil. 2018; 159(12): 466-469.

Kulcsszavak: pitvarfibrilláció, thromboembolia, antikoaguláns terápia

\section{The efficacy and safety of edoxaban in non-valvular atrial fibrillation}

The significantly increased incidence of stroke and systemic embolisation caused by atrial fibrillation can be prevented by adequately adjusted anticoagulant therapy. Vitamin K antagonists effectively decrease the risk of thromboembolic events but this effect is influenced by many factors. The development of the new direct oral anticoagulant drugs (DOAC) in the last few years provided new opportunities for us to choose the suitable anticoagulant therapy. According to the results of the ENGAGE AF-TIMI 48 and ENSURE-AF multicenter, randomized trials, edoxaban, the recently introduced DOAC is equally effective as the traditional coumarin therapy, nevertheless, it ensures more tolerable anticoagulation for patients suffering from non-valvular atrial fibrillation.

Keywords: atrial fibrillation, thromboembolism, anticoagulant therapy

Szegedi A, Csanádi Z. [The efficacy and safety of edoxaban in non-valvular atrial fibrillation]. Orv Hetil. 2018; 159(12): 466-469.

(Beérkezett: 2017. december 6.; elfogadva: 2018. január 18.)

\section{Rövidítések}

DOAC $=$ direkt orális antikoaguláns $; \mathrm{ESC}=($ European Society of Cardiology) Európai Kardiológiai Társaság; INR = (international normalized ratio) nemzetközi normalizált arány; $\mathrm{PF}=$ pitvarfibrilláció; SzE = szisztémás embolizáció; TEE = transoesophagealis echokardiográfia; TTR = (time in therapeutic range) a terápiás tartományban töltött idő
A pitvarfibrilláció $(\mathrm{PF})$ a leggyakrabban előforduló tartós ritmuszavar, prevalenciája az európai népességen belül a jelen becslések szerint $2 \%$ körüli; a legfrissebb adatok szerint Magyarországon a 3\%-ot is eléri [1]. Ez a gyakoriság 30 éven belül akár a többszörösére nőhet a társadalom öregedése és a PF incidenciájának emelkedése miatt. A PF 3-5-szörös stroke-kockázattal jár, kiváltó okként az 
összes stroke-eseménynek legalább az egyötödében van jelen [2]. A thromboembolia rizikójának legerôsebb prediktora az életkor és a korábbi thromboemboliás esemény előfordulása, további prognosztikai faktor a hypertonia, a cukorbetegség, a congestiv szívelégtelenség, az érbetegség és a női nem [3]. A K-vitamin-antagonisták hatékonyan csökkentik a thromboembolia kockázatát, alkalmazásuk azonban nem problémamentes: hatékonyságukat befolyásolja az étkezés, számos gyógyszer-interakció, emellett az alvadási paraméterek monitorozását és gyakori dózismódosítást igényelnek, terápiás tartományuk keskeny. Mindezen korlátok kiküszöbölésére fejlesztették ki az új típusú, direkt orális antikoagulánsokat (DOAC), amelyek nem igénylik az alvadási paraméterek rutinszerű monitorozását, a dózis változtatását, és nagy multicentrikus, randomizált vizsgálatokban mind a thromboembolia, mind a vérzéses szövődmények előfordulása alapján legalább egyenértékứnek (noninferior) bizonyultak a warfarinnal történő összehasonlításban [4]. A DOAC-csoport 4. tagjaként 2017 júniusától az edoxabán is elérhetővé vált Magyarországon 70\%-os támogatás mellett.

\section{ENGAGE AF-TIMI 48 vizsgálat}

Az edoxabán az aktivált Xa-faktor direkt, reverzibilis gátlásán keresztül hat. A szert az ENGAGE AF-TIMI 48 multicentrikus, randomizált, kettős vakvizsgálat eredményei alapján Európában és Észak-Amerikában egyaránt törzskönyvezték stroke és szisztémás embolizáció (SzE) megelőzésére olyan nonvalvularis pitvarfibrillációban szenvedő betegeknél, akiknél egy vagy több thromboemboliás kockázati tényező jelen van. A vizsgálati eredmények alapján a hatásosság szempontjából az edoxabán noninferiornak, a biztonságosság terén szuperiornak bizonyult az INR-érték alapján beállított warfarinterápiához képest: 20\%-kal csökkentette a major vérzés, 50\%kal pedig a koponyaưri vérzés előfordulását úgy, hogy a warfarinterápia átlagos TTR-értéke kiemelkedően magas, $68,4 \%$ volt [5].

A beválasztott betegek véletlenszerúen 1:1:1 arányban részesültek warfarin, magas dózisú edoxabán- (napi $1 \times 60 \mathrm{mg})$ vagy alacsony dózisú edoxabán- (1×30 mg) kezelésben. Mindkét edoxabáncsoportban a szert a felére csökkentett adagban alkalmazták az alábbi feltételek bármelyikének fennállása esetén: 1) A kreatininclearance 30-50 ml/min; 2) $60 \mathrm{~kg}$ alatti testsúly; 3) potens P-glikoprotein-gátló (kinidin, verapamil, dronaderon, ciklosporin) együttes alkalmazása. Eszerint tehát a $60 \mathrm{mg}$ edoxabánra randomizált csoport betegeinek egy része 30 mg-ot, a $30 \mathrm{mg}$ dózisra randomizált csoport betegei részben 15 mg-ot kaptak. A randomizáció után egy hónappal a 3 különböző (60 mg, $30 \mathrm{mg}, 15 \mathrm{mg}$ ) adagot szedő betegek közül véletlenszerúen kiválasztottakban megmérték az anti-Xa-faktor-aktivitást $(\mathrm{n}=2865)$ és a szérum-edoxabánkoncentrációt $(\mathrm{n}=6780)$. Igazolták, hogy az adag 60 mg-ról 30 mg-ra csökkentése a szérumedoxabánkoncentráció 29\%-os és az anti-Xa-aktivitás 20\%-os csökkenésével jár, míg a 30 mg-ról 15 mg-ra történő redukció ugyanezen mérôszámokban 35\%-os és 25\%-os csökkenést okoz. A közel 3 éves utánkövetés alatt a szérum-edoxabánkoncentráció emelkedésével lineárisan csökkent a stroke és a szisztémás embolizáció előfordulása, a major vérzéses esetek száma viszont meredeken emelkedett, kivéve a koponyaúri vérzés előfordulását, amely számottevően nem változott [2] (1. ábra).

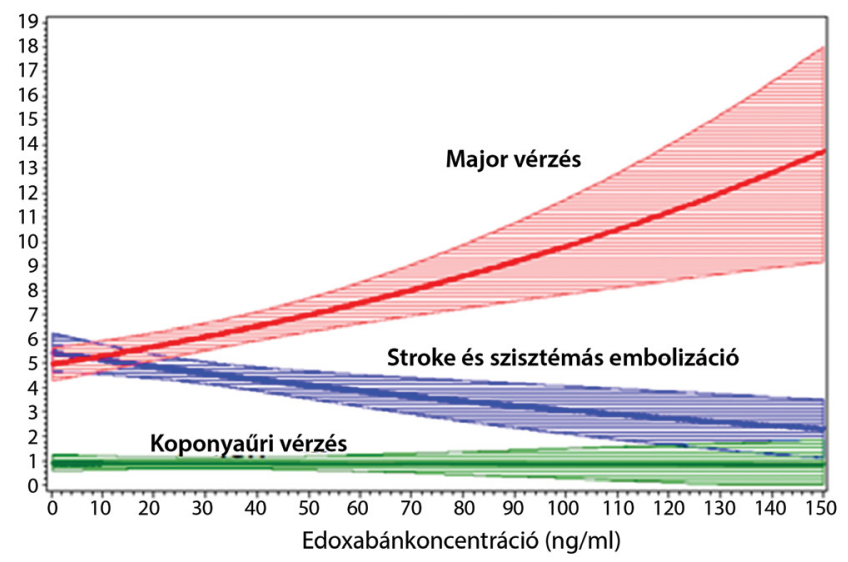

\begin{tabular}{l|l} 
1. ábra & Primer végpontok előfordulása 3 éves utánkövetés alatt a 29.
\end{tabular} napon mért edoxabánkoncentráció függvényében

A vizsgálat utólagos elemzése során összehasonlították a csökkentett dózisú edoxabán hatékonyságát és biztonságosságát is a warfarinág azon betegein elért eredményekkel, akiknél a fent említett rizikófaktorok egyike szintén jelen volt (alacsony testsúly, beszúkült vesefunkció, P-glikoprotein-inhibitor). Kimutatták, hogy ezekben az eleve magasabb rizikóval rendelkező, „fragilis” betegekben warfarin mellett a major vérzések száma jelentősen emelkedett volt azon warfarincsoporthoz képest, amelyben a három rizikótényező egyike sem fordult elő $(4,85 \%$ vs. 3,02\%). Ugyanezen fragilis betegeknél a csökkentett dózisú edoxabán alkalmazásával csupán nem szignifikáns mértékben fokozódott a major vérzések száma (60 mg 2,66\% vs. 30 mg 3,05\%). A dóziscsökkentett csoportban az elsődleges biztonságossági végpontként szereplő major vérzések relatív rizikója edoxabán adása mellett 37\%-kal csökkent a warfarinághoz képest (a vizsgálat egészében a relatív rizikócsökkentés mértéke edoxabánnal $20 \%$ volt). Mindezek alapján elmondható, hogy az edoxabán biztonságosság szempontjából megmutatkozó elónyei éppen a legmagasabb rizikójú, fragilis betegekben érvényesülnek a legmarkánsabban (1. táblázat). 
ENGAGE AF-TIMI 48 vizsgálat: elsődleges végpontok. A hatékonysági és biztonságossági végpontok előfordulása a randomizáció (warfarin vs edoxabán magas dózis, warfarin vs. edoxabán alacsony dózis) és a dóziscsökkentési kritériumok (vesefunkció, testsúly, P-glikoprotein-inhibitor) alapján létrejött alcsoportbontásban láthatók. A warfarint valamennyi beteg a 2-3 közötti INR-célértéknek megfelelően szedte, függetlenül a fragilitási kritérium jelenlététől (részletesen l. a szövegben)

\begin{tabular}{|c|c|c|c|c|c|c|}
\hline & \multicolumn{2}{|c|}{ Warfarin } & \multicolumn{2}{|c|}{ Edoxabán magas dózis } & \multicolumn{2}{|c|}{ Edoxabán alacsony dózis } \\
\hline & \multicolumn{2}{|c|}{ Dóziscsökkentési kritérium } & \multicolumn{2}{|c|}{ Dóziscsökkentési kritérium } & \multicolumn{2}{|c|}{ Dóziscsökkentési kritérium } \\
\hline & $\begin{array}{c}\text { Nincs } \\
\mathrm{n}=5249\end{array}$ & $\begin{array}{c}\text { Van } \\
\text { („fragilis betegek”) } \\
\mathrm{n}=1787\end{array}$ & $\begin{array}{c}\text { Nincs } \\
60 \mathrm{mg} \\
\mathrm{n}=5251\end{array}$ & $\begin{array}{c}\text { Van } \\
30 \mathrm{mg} \\
\mathrm{n}=1784\end{array}$ & $\begin{array}{c}\text { Nincs } \\
30 \mathrm{mg} \\
\mathrm{n}=5249\end{array}$ & $\begin{array}{c}\text { Van } \\
15 \mathrm{mg} \\
\mathrm{n}=1785\end{array}$ \\
\hline Stroke, szisztémás embolizáció & $1,29 \%$ & $2,21 \%$ & $1,00 \%$ & $1,79 \%$ & $1,38 \%$ & $2,36 \%$ \\
\hline Ischaemiás stroke & $0,82 \%$ & $1,29 \%$ & $0,77 \%$ & $1,24 \%$ & $1,18 \%$ & $2,30 \%$ \\
\hline Összmortalitás & $1,44 \%$ & $2,37 \%$ & $1,36 \%$ & $2,00 \%$ & $1,14 \%$ & $2,22 \%$ \\
\hline Major vérzés & $3,02 \%$ & $4,85 \%$ & $2,66 \%$ & $3,05 \%$ & $1,65 \%$ & $1,50 \%$ \\
\hline Koponyaűri vérzés & $0,73 \%$ & $1,26 \%$ & $0,34 \%$ & $0,57 \%$ & $0,29 \%$ & $0,14 \%$ \\
\hline GIT vérzés & $1,16 \%$ & $1,47 \%$ & $1,53 \%$ & $1,45 \%$ & $0,81 \%$ & $0,83 \%$ \\
\hline
\end{tabular}

GIT = gastrointestinalis; INR = nemzetközi normalizált arány

2. táblázat $\mid$ ENSURE-AF klinikai vizsgálat alatt a primer hatásossági és biztonságossági végpontok eredményei [6]. A legszembetűnőbb különbség a cardiovascularis mortalitásban volt, mely l $(0,1 \%)$ esetben fordult elő az edoxabán- és $5(0,5 \%)$ esetben a warfarin-enoxaparin csoportban. Azon betegek száma, akiknél TEE-vizsgálattal thrombust találtak a bal pitvari fülcsében, az edoxabán- $(\mathrm{n}=47 ; 8 \%)$ és a warfarin- $(\mathrm{n}=42 ; 7,1 \%)$ csoportban szignifikánsan nem különbözött. Kiemelendő, hogy intracranialis vérzés egyik oldalon sem fordult elő [6]

\begin{tabular}{|c|c|c|c|c|c|c|}
\hline & \multicolumn{2}{|c|}{ TEE + non-TEE-csoport } & \multicolumn{2}{|c|}{ TEE-csoport } & \multicolumn{2}{|c|}{ non-TEE-csoport } \\
\hline & $\begin{array}{l}\text { Edoxabán } \\
\mathrm{n}=1095\end{array}$ & $\begin{array}{c}\text { Warf/enox } \\
\mathrm{n}=1104\end{array}$ & $\begin{array}{l}\text { Edoxabán } \\
\text { n = 589 }\end{array}$ & $\begin{array}{c}\text { Warf/enox } \\
\text { n }=594\end{array}$ & $\begin{array}{c}\text { Edoxabán } \\
\mathrm{n}=506\end{array}$ & $\begin{array}{c}\text { Warf/enox } \\
\mathrm{n}=510\end{array}$ \\
\hline Primer végpont & $5(<1 \%)$ & $11(1 \%)$ & $2(<1 \%)$ & $5(1 \%)$ & $3(1 \%)$ & $6(1 \%)$ \\
\hline Koponyaüri vérzés & 0 & 0 & 0 & 0 & 0 & 0 \\
\hline Szisztémás embolizáció & $1(<1 \%)$ & $1(<1 \%)$ & $1(<1 \%)$ & $1(1 \%)$ & 0 & 0 \\
\hline Myocardialis infacktus & $2(<1 \%)$ & $3(<1 \%)$ & 0 & $2(<1 \%)$ & $2(<1 \%)$ & $1(<1 \%)$ \\
\hline Cardiovascularis mortalitás & $1(<1 \%)$ & $5(<1 \%)$ & $1(<1 \%)$ & 0 & 0 & $5(1 \%)$ \\
\hline Stroke & $2(<1 \%)$ & $3(<1 \%)$ & 0 & $2(<1 \%)$ & $2(<1 \%)$ & $1(<1 \%)$ \\
\hline
\end{tabular}

TEE $=$ transoesophagealis echokardiográfia

\section{Az ENSURE-AF vizsgálat eredményei}

Az ENGAGE AF-TIMI 48 vizsgálatban kevés számú cardioversio történt, ami nem biztosított elegendő információt az edoxabán hatékonyságáról és biztonságosságáról elektromos cardioversióra váró, illetve azon áteső betegek esetében [6]. A 2016 augusztusában publikált ENSURE-AF multicentrikus, prospektív, randomizált vizsgálat során összehasonlították az edoxabán és a warfarin-enoxaparin kezelés hatékonyságát és biztonságosságát krónikusan pitvarfibrilláló, cardioversióra váró betegekben. A tanulmányba 2014. március 25. és 2015. október 28. között összesen 2199 beteget vontak be, akiknél $1: 1$ arányban edoxabán- $(\mathrm{n}=1095)$ vagy warfarin-enoxaparin terápiát $(\mathrm{n}=1104)$ indítottak. Az átlagéletkor 64 évnek adódott, a bevont betegek átlagos
CHADS-VASc-score-értéke 2,6 volt mindkét csoportban. A warfarincsoportban az esetek 70,8\%-ában volt az INR a terápiás tartományban. Az edoxabáncsoportban a compliance meghaladta a 99\%-ot. A betegeket az alapján, hogy két hónapnál rövidebb vagy hosszabb ideig részesültek terápiásnak tekinthető antikoagulációban, vagy transoesophagealis echokardiográfia (TEE) által vezérelt $(\mathrm{n}=1183)$, vagy TEE nélkül elvégzett cardioversiós csoportba $(\mathrm{n}=1016)$ sorolták. A vizsgálat során alkalmazott edoxabán napi dózisa $60 \mathrm{mg}$ volt, a dózis felezésére (30 mg) a következő esetekben került sor: kreatininclearance $15-50 \mathrm{ml} / \mathrm{min},<60 \mathrm{~kg}$ testsúly, bizonyos P-glikoprotein-gátlók egyidejü alkalmazása [6]. Mivel az edoxabánnak csak elenyészően kis része metabolizálódik a citokróm P450-es enzimrendszerén keresztül $(<4 \%)$, a pitvarfibrillációban gyakran használt amio- 
daron mellett dóziscsökkentésre nem volt szükség [4, 7].

A primer hatásossági végpont a stroke, a koponyüri vérzés, a szisztémás embolizáció, a myocardialis infarctus és a cardiovascularis mortalitás összesített előfordulása volt. Összesen 5 esemény $(<1 \%)$ volt észlelhető az edoxabáncsoportban, ezzel szemben 11 esemény (1\%) a warfarin-enoxaparin csoportban (2. táblázat). A primer biztonságossági végpont a vizsgálat ideje alatt megjelenő súlyos és a klinikailag releváns nem súlyos vérzés volt, ami alacsony abszolút számértéket mutatott akár az alkalmazott TEE-módszerrel, akár a nélkül. Annak ellenére, hogy az ENSURE-AF a legnagyobb betegszámú cardioversiós AF-vizsgálat, fontos tudni, hogy több mint tízezer beteg bevonására lett volna szükség ahhoz, hogy megfelelő statisztikai erôvel rendelkezzen a vizsgálat az edoxabán- és a standard terápia közötti hatékonysági vagy biztonságossági különbség kimutatására az alacsony eseményráta miatt.

\section{Következtetés}

Mindezek alapján megállapítható, hogy az edoxabán a hagyományos tartós orális antikoaguláns terápiához hasonlóan hatásos, ugyanakkor jobban tolerálható véralvadásgátló kezelést jelent a nem valvularis hátterü pitvarfibrillációban szenvedő betegek körében [8]. Az edoxabán alkalmazása során csak napi egyszeri dózis adására van szükség, mely a terápiahűséget javíthatja, dózisredukcióra a leggyakrabban alkalmazott antiaritmiás szer, az amiodaron mellett sincs szükség. Nephropathiában szenvedő idős betegek esetén az edoxabán megfelelő választás lehet, mivel csökkentett dózisban (napi $30 \mathrm{mg}$ ) $15 \mathrm{ml} /$ min-es kreatininclearence-ig adható [9]. AZ ENSUREAF vizsgálat eredményei alapján az alkalmazási előiratba is bekerült, hogy akiknél cardioversiót terveznek, a fülcsethrombus kizárását követően a cardioversio már két órával a gyógyszer bevételét követően biztonsággal elvégezhetố az edoxabán gyors felszívódásának köszönhetően (a maximális plazmakoncentrációt ugyanis 1-2 órán belül eléri). Az ENGAGE AF vizsgálat eredményei is hozzájárultak ahhoz, hogy az ESC 2016. évi, a pitvarfibrilláció kezelésére vonatkozó ajánlásába bekerülhetett az, hogy pitvarfibrilláció fennállása esetén, amennyiben tar- tós antikoaguláns terápiára van szükség, a K-vitamin-antagonisták helyett a DOAC-terápia részesítendő előnyben (I. osztályú ajánlás) [3].

Anyagi támogatás: A közlemény megjelenését az MSD Pharma Hungary Kft. tette lehetővé.

Szerzői munkamegosztás: A szerzők egyenlő mértékben járultak hozzá a közlemény elkészültéhez. A cikk végleges változatát a szerzók elolvasták és jóváhagyták.

Érdekeltségek: A szerzőknek nincsenek érdekeltségeik.

\section{Irodalom}

[1] Tomcsányi J, Salfer B, Nagy B. Old and new oral anticoagulants in the management of atrial fibrillation. Hungarian data. [Régi és új orális antikoagulánsok hazai alkalmazása pitvarfibrillációban.] Orv Hetil. 2017; 158: 1545-1549. [Hungarian]

[2] Ruff TC, Giugliano RP, Braunwald E, et al. Association between edoxabán dose, concentration, anti-Factor Xa activity, and outcomes: an analysis of data from the randomised, double-blind ENGAGE AF-TIMI 48 trial. Lancet 2015; 385: 2288-2295

[3] Kirchhof P, Benussi S, Kotecha D, et al. 2016 ESC Guidelines for the management of atrial fibrillation developed in collaboration with EACTS. Eur Heart J. 2016; 37: 2893-2962.

[4] De Caterina R, Ageno W, Boriani G, et al. Edoxabán in atrial fibrillation and venous thromboembolism - ten key questions and answers: A practical guide. Adv Ther. 2017; 34: 620-637.

[5] Giugliano RP, Ruff CT, Braunwald E, et al. Edoxabán versus warfarin in patients with atrial fibrillation. N Engl J Med. 2013; 369: 2093-2104.

[6] Goette A, Merino JL, Ezekowitz MD, et al. Edoxabán versus enoxaparin-warfarin in patients undergoing cardioversion of atrial fibrillation (ENSURE-AF): a randomised, open-label, phase 3b trial. Lancet 2016; 388: 1995-2003.

[7] Bounameaux H, Camm AJ. Edoxabán: an update on the new oral direct factor Xa inhibitor. Drugs 2014; 74: 1209-1231.

[8] McCormack PL. Edoxabán: a review in nonvalvular atrial fibrillation. Am J Cardiovasc Drugs 2015; 15: 351-361.

[9] Lixiana: Summary of product characteristics. European Medicines Agency. Available from: http://www.ema.europa.eu/ docs/en_GB/document_library/EPAR_-_Product_Information/human/002629/WC500189045.pdf [accessed: November 8,2015$]$.

(Szegedi Andrea dr., Debrecen, Móricz Zsigmond körút 22., 4032 e-mail: andiszegedi@gmail.com)

Az összefoglaló közlemény megjelenését az MSD Pharma Hungary Kft. tette lehetővé.

Az itt közölt információk a szerzők véleményét tükrözik, amely eltérhet az MSD Pharma Hungary Kft. álláspontjától.

A megemlített termékek használatakor az érvényes alkalmazási elóírás az irányadó. 